50

谓

報

之そ集めて建築す万風より發生する6のと考 へられる。之は皘上げることか中心をするか

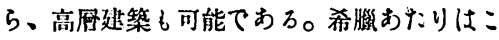
の住居型式によつたものである。:の型式は 丘上などにより易く、アーキなども發現する。 :の(3)に該賞するものはォージェルニュ地方 に多い。:つに問題となるのは丘上聚落の起 源であろ。地中海沿岸には今なほ丘上聚落が 發達してふる。聚落が次第に低、地に降万傾 向おりとは多くの人々によって唱えられる所 であるが之は必らすしも一般的とは云い蜼 い。而して地中海方面に潑遵してるら兵上聚 落の分布はカーヴェルニュにまで及んである それより北には見られない。

入

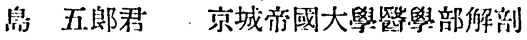
學较空

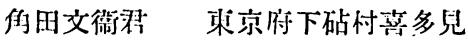

\section{埥 居}

高畸位太郎君京都市上京區小川大野町71 （因みに第46卷 第 11 號添附の會只名簿に高橋

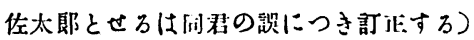

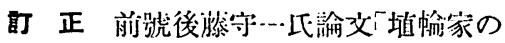

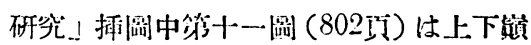
倒してるるからてっに訂诈して道く。 